State Reports will be familiar with the style and most of the matter of this book, it is an undoubted advantage to have the information within reasonable compass.

But Dr. Ries has not merely produced a condensed epitome of earlier publications; he has prepared a well-balanced, thoroughly practical work on American clays and clay-products, including a capital summary of our knowledge of the properties of clays in general. The whole has been brought well up to date.

The author treats his subject under the following heads:--(r) The origin of clay, (2) chemical properties, (3) physical properties, (4) kinds of clay, (5) methods of mining and manufacture, (6) distribution of clav in the United States, (7) Fuller's earth.

The distribution of the clays is considered under each State separately, according to the geological age of the formations; but an excellent index enables references to particular kinds of clay to be found readily.

It may be remarked that we are still in the dark as to the cause of plasticity in clays, in spite of the numerous theories; nor has any generally applicable method of measuring this property been discovered. Dr. Ries discusses the subject with great fairness. We heartily commend his views upon the loose way in which kaolin and kaolinite are so often confused, and especially his objection to the assumption that kaolinite is the normal basis of all clays; a brief comparison of analyses at once dispels this idea.

This book is very well produced and free from slips, but we. are somewhat puzzled by the "increase in texture " mentioned on p. Io7.

\section{THE AETIOLOGY OF LEPROSY.}

On Leprosy and Fish Eating. A Statement of Facts and Explanations. By Jonathan Hutchinson. F.R.C.S., F.R.S. Pp. xxiv +420 . (London: Archibald Constable and Co., Ltd., r9o6.) Price i2s. $6 d$. net.

T

$\mathrm{E}$ object of this work is stated in the preface to be "to carry conviction to the reader that the fundamental cause of the malady known as true leprosy is the eating of fish in a state of commencing decomposition." The various districts in which leprosy occurs have been examined, and it is found that in practically all fish is consumed as an article of diet, often in a more or less stale condition, the prevalence of the disease frequently being in a direct ratio to the amount of fish eaten. Mr. Hutchinson would associate the former prevalence of leprosy in the British Isles and in Europe with the Roman Catholic ordinances prescribing fish-food on two out of every three week-days, its decline in these countries with the relaxation of discipline which preceded the Reformation, its extinction with the establishment of Protestantism.

We think that Mr. Hutchinson goes much too far in thus ascribing all variations in the prevalence of leprosy as being correlated with those of a fish-diet; NO. I 948 , VOL. 75$]$ even in the fact that the disease is more prevalent among men than among women he sees support for his hypothesis, for he suggests that women are more fastidious feeders than men, that men would be more likely than women to obtain fish if this were expensive, and so on. Why fish fresh or properly salted does not convey the disease and only bad fish does is by no means clear, the single suggestion given being that there may be some connection between tuberculosis and leprosy, and that fish-diet may contain some constituent which may modify the tubercle bacillus and convert it into the leprosy bacillus! Mr. Hutchinson maintains that the facts he has collected point to the conclusion that the efficient cause of leprosy must be some article of food (p. 33), and that fish is the only one of universal occurrence which can be traced.

But is it necessary to find a single mode of origin for the disease in every part of the world? Surely not, and if so there is no need to limit it to fish. Mr. Hutchinson admits that personal contact may convey the disease, but declares that this mode of infection is exceedingly rare, "where one had acquired the disease, hundreds equally exposed to risk had escaped"' ( $p$. viii). But the latter statement proves little; all of us who live in big towns must daily come in contact with the virus of tuberculosis, yet only an unfortunate few contract the disease. Similarly, as regards the decline of leprosy, most, if not all, infective diseases show periods of epidemic prevalence and of decline; to what can be ascribed the disappearance of plague and of malaria from England? Mr. Hutchinson says the world-wide distribution of leprosy proves that "it is not solely dependent upon contagion"; this does not appear to mean personal contact, but to suggest an origin de novo. Would not the same apply almost equally to tuberculosis, but would it be said that therefore the last-named disease is capable of " independent origination"? In the case of tuberculosis, often many years may in all probability intervene between infection and manifestation; in leprosy we do not know how long the virus may lie latent, and therefore an exposure long forgotten may really be the determining cause of the attack, without bringing in a de novo origin, in those rare cases in which it has not been possible to trace the source of infection.

Lesions of the nasal mucous membrane are extremely frequent in lepers, and the nasal discharge may therefore be the chief vehicle by which the virus is disseminated. It has also recently been reported that the mosquito and the bed-buos may harbour the bacillus, further channels again by which infection may be carried. These, together with the close contact and promiscuous intercourse which exist between the members of native races, seem to us sufficient to explain the source of infection in leprosy, fish-diet being only a remarkable coincidence.

In thus criticising Mr. Hutchinson's theory we do not in the least desire to belittle his work, which is of the greatest interest, and his book is a valuable contribution to the epidemiology of leprosy. 